\title{
SIMULATING THE VERNALIZATION RESPONSE OF THE “SNOW QUEEN" LILY (Lilium longiflorum Thunb.)
}

\author{
Nereu Augusto Streck*; Mariângela Schuh \\ UFSM/CCR - Depto. de Fitotecnia - 97105-900 - Santa Maria, RS - Brasil. \\ *Corresponding author <nstreck1@smail.ufsm.br>
}

\begin{abstract}
Vernalization is a process required by certain plant species, including lilies (Lilium spp.), to enter the reproductive phase, through an exposure to low, non-freezing temperatures. The objective of this study was to evaluate a nonlinear vernalization response function for the "Snow Queen" lily. An experiment was carried out in Santa Maria, RS, Brazil, to provide an independent data set to evaluate the performance of the model. Lily bulbs were vernalized at $-0.5,4.0$, and $10^{\circ} \mathrm{C}$ during two, four, six, and eight weeks. The daily vernalization rate (fvn) for each treatment was calculated with a beta function, and the effective vernalization days (VD) were calculated by accumulating fvn. The thermal time from plant emergence to visible buds at different VD treatments was used as the observed response to VD. Lily plants were not vernalized at values less than eight effective vernalization days and were fully vernalized at values greater than 40 days. The generalized nonlinear vernalization function described well the "Snow Queen" lily developmental response to VD, with a root mean square error of 0.178 .

Key words: low temperature, flowering, bulb, model, plant development

\section{SIMULAÇÃO DA RESPOSTA À VERNALIZAÇÃO DO LÍRIO "SNOW QUEEN" (Lilium longiflorum Thunb.)}

\begin{abstract}
RESUMO: A vernalização é um processo que certas espécies de plantas, incluindo lírios (Lilium spp.), necessitam para entrar no período reprodutivo, por meio da exposição a baixas temperatures. Avaliou-se uma função não linear de resposta a vernalização para o lírio a -0,5; 4,0 e 10,0 ${ }^{\circ} \mathrm{C}$ durante dois, quatro, seis e oito semanas. Dados de duração do subperíodo compreendido do plantio dos bulbos até o aparecimento do botão das plantas com lírio, cultivar “Snow Queen”, provenientes de um experimento realizado em Santa Maria, RS, Brasil, foram usados como dados independentes para testar a função não linear de vernalização. Plantas de lírio não foram vernalizadas com menos de oito dias efetivos de vernalização enquanto que as plantas estavam completamente vernalizadas com 40 ou mais dias efetivos de vernalização. A função geral não linear de vernalização descreveu bem a resposta de desenvolvimento à vernalização com uma raiz quadrada média do erro de 0,178 .

Palavras-chave: baixa temperatura, florescimento, bulbos, modelo, desenvolvimento vegetal
\end{abstract}

\section{INTRODUCTION}

Lilies (Lilium spp.) belong to one of the six more important genera of flower bulbs produced worldwide (De Hertogh \& Le Nard, 1993). The importance of this genus in the world flower market is in large part due to the diversity of the species and the large number of hybrids and cultivars commercially available (De Hertogh, 1996). Major markets for lily include fresh cut flowers, potted flowering plants, gardens and landscapes (De Hertogh, 1996; Grassotti, 1996; Mynett, 1996).

Three phases can be distinguished during the development of lilies (Langens-Gerrits et al., 2003): the juvenile, the vegetative, and the flowering phase. Plants from juvenile bulblets have a "rosette" growing habit, i.e., very short internodes, and will not flower. After one or two growing seasons, bulbs sprout with a stem that elongates and flowers (Langens-Gerrits et al., 2003).
Most of lily species require an exposure to low, non-freezing, temperatures to accelerate shoot emergence and flowering (Weiler \& Langhans, 1968; Roh \& Wilkins, 1977a; Roh, 1985; Choi et al., 1996). The exposure to low temperatures either in natural or in artificial cold treatment is called vernalization (Purvis \& Gregory, 1937; 1952; Purvis, 1961). Vernalization is a natural survival mechanism common to certain fall planted species to tolerate low temperatures during the winter (Jedel et al., 1986; Wang et al., 1995; Rawson et al., 1998). Lily plants respond to vernalization by decreasing their time to flowering (i.e., there is an increase in the development rate towards flowering as vernalization progresses). The decrease in the time to flowering is caused by a decrease in the number of primordia that become leaves, i.e., a decrease in final leaf number (Roh \& Wilkins, 1977a; 1977b; Roh, 1985). 
Plant response to vernalization is given by the combination of two factors, the temperature during the vernalization period, and the duration of the period. The duration of the exposure to vernalizing temperatures is measured as effective vernalization days (VD). One VD is attained when the plant is exposed to the optimum temperature for vernalization for a period of one day (24 h). As temperature departs from the optimum, only a fraction of one VD is accumulated by the plant at a given calendar day (Hodges \& Ritchie, 1991; Ritchie, 1991). Response to vernalization may also be dependent on plant age and plant physiological stage (Roh, 1985; Slafer \& Rawson, 1994; Langens-Gerrits et al., 2003).

Because the exposure to low temperatures affects plant development in many species, vernalization models have been developed for several crops such as winter wheat (Triticum aestivum L.) (Ritchie, 1991; Wang \& Engel, 1998; Streck et al., 2003), carrot (Daucus carota L.) (Yan \& Hunt, 1999), calabrese (Brassica oleracea var. italica) (Wurr et al., 1995), lily (Lilium spp.) (Streck, 2002), and onion (Allium cepa L.) (Streck, 2003). These vernalization models account for the effect of VD on the development rate in many crop simulation models. Vernalization models are composed by a response function for VD [vernalization function, $f(V D)$ ], which varies from 0 to 1 , as a modifier of the development rate (e.g. Weir et al., 1984; Ritchie, 1991; Wang \& Engel, 1998).

Streck (2002) proposed a generalized nonlinear $f(V D)$ for lily. The nonlinear vernalization function has coefficients with biological meaning and described well the lily developmental response to VD in 10 lily genotypes with a wide range of vernalization responses. However, the vernalization response function proposed by Streck (2002) was not evaluated for the Lilium longiflorum Thunb, cultivar "Snow Queen", one of the most important lily cultivars grown in Brazil, which constitutes the rationale for this effort. The objective of this study was to evaluate the nonlinear vernalization response function proposed by Streck (2002) for the “Snow Queen” lily.

\section{MATERIAL AND METHODS}

Results on the effect of VD on time to flowering in other species (e.g. wheat) suggest a sigmoidal shaped curve for describing the plant developmental response to VD (e.g. Chujo, 1966; Wang et al., 1995; Brooking, 1996; Rawson et al., 1998; Mahfoozi et al., 2001). Streck (2002) proposed the following MMF response function (Morgan et al., 1975) as a generalized vernalization response function [f(VD)] in lily:

$f(V D)=(V D)^{5} /\left[(22.5)^{5}+(V D)^{5}\right]$

$\mathrm{f}(\mathrm{VD})$ varies in Equation (1) from 0 to 1, with $\mathrm{f}(\mathrm{VD})=0$ corresponding to the response of unvernalized plants and
$f(V D)=1$ to the response of fully vernalized plants. The coefficient 22.5 is the VD when the response is one half of the response of fully vernalized plants, i.e., when $\mathrm{f}(\mathrm{VD})$ is 0.5 . The coefficient 5 gives the sigmoidal response to $\mathrm{VD}$, resulting in a response close to zero for values less than $10 \mathrm{VD}$ and close to 1 for values higher than $40 \mathrm{VD}$.

A trial with the "Snow Queen" cultivar was carried out in Santa Maria, RS, Brazil (latitude: 2943'S, longitude: $53^{\circ} 48^{\prime} \mathrm{W}$ and altitude: $95 \mathrm{~m}$ ), to provide an independent data set to evaluate the performance of equation (1). The treatments consisted of bulbs vernalized at -0.5 , 4.0 , and $10^{\circ} \mathrm{C}$ during two, four, six, and eight weeks inside cold chambers. Only adult bulbs were used in this study, as juvenile bulblets (Langens-Gerrits et al., 2003) would not be appropriate for our goal.

To represent temperature and calendar day treatments as vernalization days in the experiment, the following approach was used. The daily vernalization rate [fvn, $\left(\right.$ day $\left.\left.^{-1}\right)\right]$ for each vernalization treatment was calculated with a beta function (Wang \& Engel, 1998; Streck et al., 2003):

$$
\begin{aligned}
& \text { fvn }=\left[2\left(\mathrm{~T}_{\mathrm{m}} \mathrm{T}_{\text {min }}\right)^{\alpha}\left(\mathrm{T}_{\mathrm{opt}}-\mathrm{T}_{\text {min }}\right)^{\alpha}-\left(\mathrm{T}-\mathrm{T}_{\text {min }}\right)^{2 \alpha}\right] /\left(\mathrm{T}_{\mathrm{opt}}-\mathrm{T}_{\text {min }}\right)^{2 \alpha} \\
& \text { for } \mathrm{T}_{\min } \leq \mathrm{T} \leq \mathrm{T}_{\max } \\
& \text { fvn }=0 \quad \text { for } \quad \mathrm{T}<\mathrm{T}_{\min } \text { or } \mathrm{T}>\mathrm{T}_{\max } \\
& \alpha=\ln 2 / \ln \left[\left(\mathrm{T}_{\max }-\mathrm{T}_{\min }\right) /\left(\mathrm{T}_{\mathrm{opt}}-\mathrm{T}_{\min }\right)\right]
\end{aligned}
$$

where $\mathrm{T}_{\text {min }}, \mathrm{T}_{\text {opt }}$, and $\mathrm{T}_{\max }$ are the cardinal temperatures (minimum, optimum, and maximum) for vernalization in lily, assumed as $-1.5,5$, and $21^{\circ} \mathrm{C}$ (Roh \& Wilkins, 1977a, Roh, 1985; Holcomb \& Berghage, 2001; Streck, 2002). The beta function (equations 2 and 3) with the cardinal temperatures for lily is represented in Figure 1 . The effective vernalization days (VD) were then calculated by:

$\mathrm{VD}=\Sigma \mathrm{fvn}$

The treatments and the associated VD used in this study are presented in Table 1.

The vernalization treatments of the bulbs ended on $12 / 05 / 2002$, when bulbs were planted inside a plastic greenhouse. The experimental design was a 3 x $4+1$ factorial design with three replications. Each replication was composed by three rows of plants, with 4 plants/row. Plant spacing was $0.15 \mathrm{~m}$ between rows and $0.15 \mathrm{~m}$ between plants. Developmental parameters of interest in this study were measured in two plants in the center row of each plot. Other plants of the plot were border plants. The experiment finished on 05/15/2003.

A widely accepted approach to quantify the vernalization response in plants is to measure the time (calendar time or thermal time) from planting or plant emergence to flowering (Chujo, 1966; Rawson et al., 1998; Streck et al., 2003). In this experiment, we used the ther- 
Table 1 - Vernalization treatments and associated effective vernalization days. Santa Maria, RS, Brazil, 2002/ 2003.

\begin{tabular}{|c|c|c|}
\hline \multicolumn{2}{|c|}{ Treatments } & \multirow{2}{*}{$\begin{array}{l}\text { Effective vernalization days } \\
\text { (VD) }\end{array}$} \\
\hline Temperature & Period & \\
\hline $10^{\circ} \mathrm{C}$ & 2 weeks & 12.04 \\
\hline $10^{\circ} \mathrm{C}$ & 4 weeks & 24.08 \\
\hline $10^{\circ} \mathrm{C}$ & 6 weeks & 36.12 \\
\hline $10^{\circ} \mathrm{C}$ & 8 weeks & 46.44 \\
\hline $4^{\circ} \mathrm{C}$ & 2 weeks & 13.89 \\
\hline $4^{\circ} \mathrm{C}$ & 4 weeks & 27.78 \\
\hline $4^{\circ} \mathrm{C}$ & 6 weeks & 41.66 \\
\hline $4^{\circ} \mathrm{C}$ & 8 weeks & 53.57 \\
\hline$-0.5^{\circ} \mathrm{C}$ & 2 weeks & 8.12 \\
\hline$-0.5^{\circ} \mathrm{C}$ & 4 weeks & 16.24 \\
\hline$-0.5^{\circ} \mathrm{C}$ & 6 weeks & 24.36 \\
\hline$-0.5^{\circ} \mathrm{C}$ & 8 weeks & 31.32 \\
\hline Unvernalized & & 0 \\
\hline
\end{tabular}

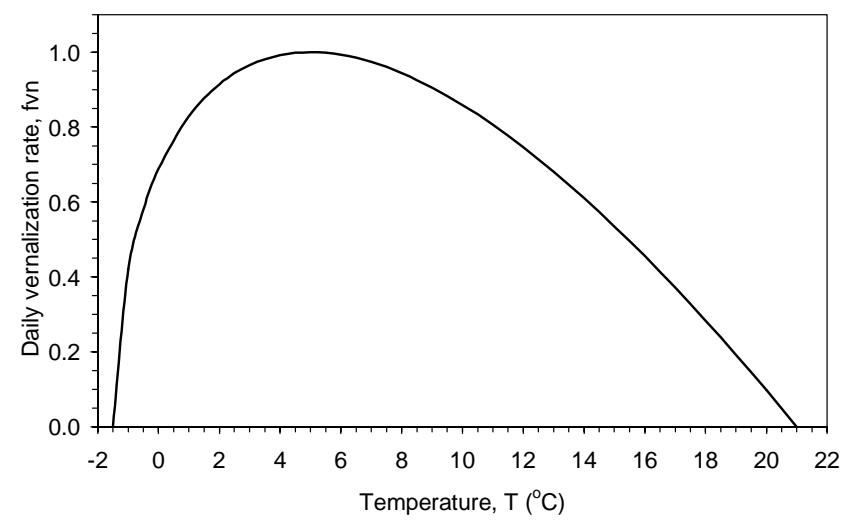

Figure 1 - Response of the beta function (equations 2 and 3) with the cardinal temperatures for vernalization in lily (as $1.5,5$, and $21^{\circ} \mathrm{C}$ ) used to calculate the daily vernalization rate [fvn] for the different vernalization treatments.

mal time from emergence (EM) to visible buds (VB), because some plants had their flowers aborted. Emergence was considered when $50 \%$ of the plants of each replication were visible above soil surface. Visible buds were considered when flower buds were visible without removing leaves (Fisher et al., 1997a). The date of visible buds for each treatment was the mean date of three replications.

Air temperature throughout the lily growing season was recorded inside the plastic greenhouse with a thermograph installed $1.5 \mathrm{~m}$ above ground inside a white shelter located at the center of the greenhouse. The daily minimum and maximum temperatures were extracted from the records. The daily mean temperature (Tmean) was calculated as the average of the daily minimum and maximum temperatures. Daily growing degree days (GDD, ${ }^{\circ} \mathrm{C}$ day) were calculated as (Gilmore \& Rogers, 1958; Arnold, 1960):

GDD $=($ Tmean $-\mathrm{Tb}) \cdot 1$ day

where $\mathrm{Tb}$ is the base temperature for lily development, assumed $3.5^{\circ} \mathrm{C}$ (Fisher et al., 1997a; 1977b). Accumulated thermal time (TT, ${ }^{\circ} \mathrm{C}$ day) from EM to VB was calculated by:

$\mathrm{TT}=\Sigma \mathrm{GDD}$

Accumulated TT data for the EM-VB phase for each vernalization treatment were normalized in order to obtain a 0 to 1 response, representing unvernalized and fully vernalized plants, respectively, by (Streck, 2002):

$\mathrm{NTT}=\left(\mathrm{TT}_{0 \mathrm{VD}}-\mathrm{TT}\right) /\left(\mathrm{TT}_{0 \mathrm{VD}}-\mathrm{TT}_{\mathrm{s}}\right)$

where NTT is the normalized accumulated TT from EM to $\mathrm{VB}, \mathrm{TT}_{0 \mathrm{VD}}$ is the accumulated $\mathrm{TT}$ from EM to $\mathrm{VB}$ of unvernalized plants, i.e. at $0 \mathrm{VD}$, TT is the accumulated $\mathrm{TT}$ from EM to $\mathrm{VB}$ for a given $\mathrm{VD}$ treatment, and $\mathrm{TT}_{\mathrm{s}}$ is the TT of the VD treatment that had the shortest accumulated TT from EM to VB. Because unvernalized plants did not produce any visible buds, $\mathrm{TT}_{0 \mathrm{VD}}$ is zero.

The NTT data were compared to the $\mathrm{f}(\mathrm{VD})$ predicted by equation (1). The root mean square error (RMSE) was calculated and used as a measure of the performance of equation (2) (Janssen \& Heuberger, 1995):

$\operatorname{RMSE}=\left[\Sigma\left(\mathrm{P}_{\mathrm{i}}-\mathrm{O}_{\mathrm{i}}\right)^{2} / \mathrm{N}\right]^{0.5}$

where $\mathrm{P}_{\mathrm{i}}=$ predicted data, $\mathrm{O}_{\mathrm{i}}=$ observed data, $\mathrm{N}=$ number of observations, and $\mathrm{i}=1$...N. The RMSE expresses the spread in $\mathrm{P}_{i}-\mathrm{O}_{i}$ and has the same dimensions as the predicted and the observed data (here dimensionless). The lower the RMSE the better the model prediction.

\section{RESULTS AND DISCUSSION}

Daily values of mean air temperature inside the plastic greenhouse during the experiment are plotted in Figure 2. Temperature was above $21^{\circ} \mathrm{C}$, the maximum temperature for lily vernalization, from planting (05 December 2002, DOY=339) to 13 March 2003 (DOY = 72), when plants from all treatments, except the unvernalized, had their buds visible. These temperatures ensured that there was no vernalization in the field. Plants from the unvernalized bulbs did not flower by 15 May 2003, when the experiment ended.

The vernalization response of lily cv. "Snow Queen" and the response predicted with the $\mathrm{f}(\mathrm{VD})$ response function proposed by Streck (2002) [equation (1)] are illustrated in Figure 3. The general trend of the observed data was described well by the Streck model. Observed data show that lily plants are not vernalized (i.e., 


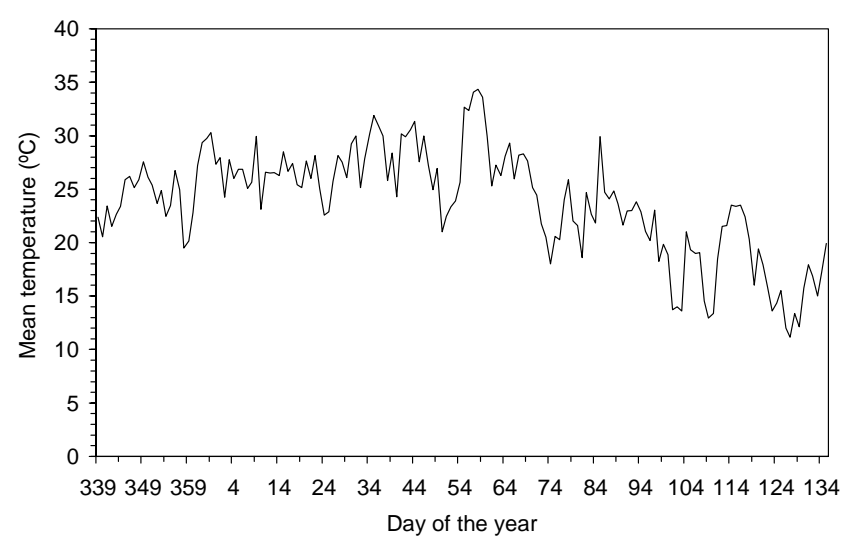

Figure 2 - Daily mean air temperature inside the plastic greenhouse throughout the lily growing season. Santa Maria, RS, Brazil, 2002/2003.

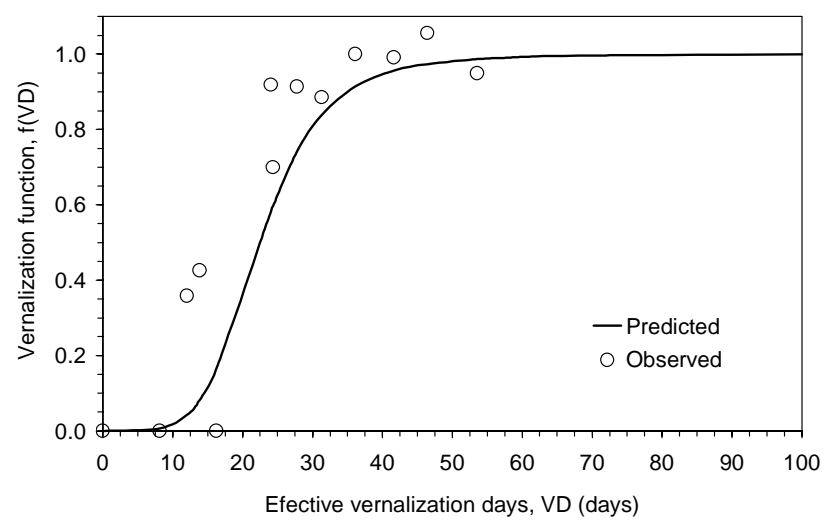

Figure 3 - The observed vernalization response of "Snow Queen” lily and the $\mathrm{f}(\mathrm{VD})$ predicted with the response function proposed by Streck (2002). Santa Maria, RS, Brazil, 2002/2003.

the response is zero) at values less than $8 \mathrm{VD}$ and fully vernalized (i.e., the response is close to one) at values greater than $40 \mathrm{VD}$, and so does the Streck model. The RMSE of the estimate was 0.178 which is greater than the RMSE of 0.089 reported by Streck (2002) when the same $f(V D)$ was used to describe the vernalization response of 10 lily genotypes with a wide range of vernalization response.

Several response functions used in crop simulation models are dependent on genotype. This creates a problem when a model needs to be used with genotypes that have unknown coefficients. Additionally, the use of Occam's Razor in crop modeling is encouraged (Sinclair \& Muchow, 1999), i.e. the simplest theory is preferred to more complex ones, or explanations of phenomena should be in terms of known quantities. This type of philosophy in crop modeling has been encouraged and it assumes that the similarities among genotypes are more important than the differences (Major \& Kiniry, 1991).

Therefore, the search for generalized response functions is a major goal in crop modeling. As shown in this study, most of the variation in the response of de- velopment of the "Snow Queen" lily to vernalization can be accounted for by the general vernalization function proposed by Streck (2002). The greater RMSE compared to that reported by Streck (2002) is because several observed points at intermediate DV values were underpredicted for the "Snow Queen" lily (Figure 3). But still, we believe that the Streck model (equation 1) is appropriate because of the following advantages. First, it is biologically realistic as biological systems are likely to respond to environmental factors in a smooth and continuous fashion (Shaykewich, 1995). Second, the function describes what is currently accepted in terms of vernalization response in plants (Slafer \& Rawson, 1994; Cao \& Moss, 1997). A short period of exposure to vernalizing temperatures (less than $10 \mathrm{VD}$ ) leads to plants behaving as if they never were exposed to vernalizing temperatures. An exposure to more than 8-10 VD causes the plant to respond and behave differently in relation to unvernalized plants. After 40-50 VD, plants are fully vernalized, i.e. there is no further response to VD. Third, the model worked well for 10 lily genotypes in a previous study (Streck, 2002) and worked also well for the "Snow Queen" lily in this study, which are independent data sets, indicating its robust and general nature.

\section{CONCLUSION}

The developmental response of the "Snow Queen" lily to vernalization can be simulated by the generalized nonlinear vernalization response function proposed by Streck (2002). Lily plants were not vernalized at values less than 8 effective vernalization days and were fully vernalized at values greater than 40 effective vernalization days.

\section{REFERENCES}

ARNOLD, C.Y. Maximum-minimum temperatures as a basis for computing heat units. Proceedings of the American Society for Horticultural Sciences, v.76, p.682-692, 1960.

BROOKING, I.R. Temperature response of vernalization in wheat: A developmental analysis. Annals of Botany, v.78, p. 507-512, 1996.

CAO, W.; MOSS, D.N. Modeling phasic development in wheat: a conceptual integration of physiological components. The Journal of Agricultural Science, v.129, p.163-172, 1997.

CHOI, S.T.; CHEONG, S.T.; AHN, H.G. Effects of planting depth and cold treatment on growth and flowering of Lilium hybrids. Acta Horticulture, n.414, p.235-242, 1996.

CHUJO, H. Differences in vernalization effects effect in wheat under various temperatures. Proceedings of the Crop Science Society of Japan, v.35, p.177-186, 1966.

DE HERTOGH, A.A. Marketing and research requirements for Lilium in North America. Acta Horticulture, n.414, p.17-24, 1996.

DE HERTOGH, A.A.; LE NARD, M. World production and horticultural utilization of flower bulbs. In: DE HERTOGH, A.A.; LE NARD, M. The physiology of flower bulbs. Amsterdam: Elsevier Science Publishers, 1993. cap.2, p.21-28.

FISHER, P.R.; HEINS, R.D.; EHLER, N.; LIETH, J.H. A decision-support system for real-time management of Easter lily (Lilium longiflorum Thunb.) scheduling and height - I. System description. Agricultural Systems, v.54, p.23-37, 1997a. 
FISHER, P.R.; HEINS, R.D.; EHLER, N.; LIETH, J.H.; BROGAARD, M.; KARLSEN, P. A decision-support system for real-time management of Easter lily (Lilium longiflorum Thunb.) scheduling and height - II. Validation. Agricultural Systems, v.54, p.39-55, 1997b.

GILMORE Jr., E.C.; ROGERS, J.S. Heat units as a method of measuring maturity in corn. Agronomy Journal, v.50, p.611-615, 1958.

GRASSOTTI, A. Economics and culture techniques of Lilium production in Italy. Acta Horticulture, n.414, p.25-34, 1996.

HODGES, T.; RITCHIE, J.T. The Ceres-wheat phenology model. In: HODGES, T. Predicting crop phenology. Boston: CRC Press, 1991. cap.12, p.133-141.

HOLCOMB, E.J.; BERGHAGE, R. Photoperiod, chilling, and light quality during daylight extension affect growth and flowering of tissue-cultured Easter lily plants. HortScience, v.36, p.53-55, 2001.

JANSSEN, P.H.M.; HEUBERGER, P.S.C. Calibration of process-oriented models. Ecological Modelling, v.83, p.55-56, 1995.

JEDEL, P.E.; EVANS, L.E.; SCARTH, R. Vernalization responses of a selected group of spring wheat (Triticum aestivum L.) cultivars. Canadian Journal of Plant Science, v.66, p.1-9, 1986.

LANGENS-GERRITS, M.; KLERK, G.; CROES, A. Phase change in lily bulblets regenerated in vitro. Physiologia Plantarum, v.119, p.590-597, 2003.

MAHFOOZI, S.; LIMIN, A.E.; FOWLER, D.B. Influence of vernalization and photoperiod responses on cold hardiness in winter cereals. Crop Science, v.41, p.1006-1011, 2001.

MAJOR, D.J.; KINIRY, J.R. Predicting daylength effects on phenological processes. In: HODGES, T. Predicting crop phenology. Boston: CRC Press, 1991. cap.4, p.15-28.

MORGAN, P.H.; MERCER, L.P.; FLODIN, N.W. General model for nutritional responses of higher organisms. Proceedings of the National Academy of Sciences of the USA, v.72, p.4327-4331, 1975.

MYNETT, K. Research, production and breeding of lilies in eastern European countries. Acta Horticulture, n.414, p.47-53, 1996.

PURVIS, O.N. The physiological analysis of vernalisation. Encyclopedia of Plant Physiology, v.16, p.76-122, 1961.

PURVIS, O.N.; GREGORY, F.G. Studies in vernalization of cereals. I. A comparative study of vernalisation in winter rye by low temperature and by short days. Annals of Botany, v.1, p.569-592, 1937.

PURVIS, O.N.; GREGORY, F.G. Studies in vernalisation of cereals. XII. The reversibility by high temperature of the vernalised condition in Petkus winter rye. Annals of Botany, v.16, p.1-21. 1952.

RAWSON, H.M.; ZAJAC, M.; PENROSE, L.D.J. Effect of seedling temperature and its duration on development of wheat cultivars differing in vernalizing response. Field Crops Research, v.57, p.289-300, 1998.

RITCHIE, J.T. Wheat phasic development. In: HANKS, R.J.; RITCHIE, J.T. Modeling plant and soil systems. Madison: ASA; CSSA; SSSA, 1991. cap.3, p.31-54.

ROH, M.S. Flowering response of mid-century hybrid lilies to bulb vernalization and shoot photoperiod treatment. HortScience, v.20, p.710713, 1985.
ROH, M.S.; WILKINS, H.F. Comparison of continuous and alternating bulb temperature treatments on the growth and flowering in Lilium longiflorum Thunb. Journal of the American Society for Horticultural Science, v.102, p.242-247, 1977a.

ROH, M.S.; WILKINS, H.F. The control of flowering in Lilium longiflorum Thunb. Cv Nellie White by cyclic or continuous light treatments. Journal of the American Society for Horticultural Science, v.102, p.247-253, 1977b.

SHAYKEWICH, C.F. An appraisal of cereal crop phenology modeling. Canadian Journal of Plant Science, v.75, p.329-341, 1995.

SINCLAIR, T.R.; MUCHOW, R.C. Occam's Razor, radiation use efficiency and vapor pressure. Field Crops Research, v.62, p.239-243, 1999.

SLAFER, G.A.; RAWSON, H.M. Sensitivity of wheat phasic development to major environmental factors: a re-examination of some assumptions made by physiologists and modelers. Australian Journal of Plant Physiology, v.21, p.393-426, 1994.

STRECK, N.A. A generalized vernalization response function for lily (Lilium spp.). Revista Brasileira de Agrometeorologia, v.10, p.221-228, 2002.

STRECK, N.A. A vernalization model in onion (Allium cepa L.). Revista Brasileira de Agrociência, v.10, p.99-105, 2003.

STRECK, N.A.; WEISS, A.; BAENZINGER, P.S. A generalized vernalization response function for winter wheat. Agronomy Journal, v.95, p.155-159, 2003

WANG, E.; ENGEL, T. Simulation of phenological development of wheat crops. Agricultural Systems, v.58, p.1-24, 1998.

WANG, S.; WARD, R.W.; RITCHIE, J.T.; FISHER, R.A.; SCHULTHESS, $\mathrm{U}$. Vernalization in wheat. I - A model based on the interchangeability of plant age and vernalization duration. Field Crops Research, v.41, p.91-100, 1995.

WEILER, T.C.; LANGHANS, R.W. Determination of vernalizing temperatures in the vernalization requirement of Lilium longiflorum (Thunb.) cv “Ace”. Proceedings of the American Society for Horticultural Science, v.93, p.623-629, 1968.

WEIR, A.H.; BRAGG, P.L.; PORTER, J.R.; RAYNOR, J.H. A winter wheat crop simulation model without water or nutrients limitations. The Journal of Agricultural Science, v.102, p.371-382, 1984.

WURR, D.C.E.; FELLOWS, J.R.; PHELPS, K.; READER, R.J. Vernalization in calabrese (Brassica oleracea var. italica) - a model for apex development. Journal of Experimental Botany, v.46, p.14871496, 1995.

YAN, W.; HUNT, L.A. Reanalysis of vernalization data of wheat and carrot. Annals of Botany, v.84, p.615-619, 1999.

Received May 05, 2004

Accepted February 18, 2005 